\title{
An Empirical Analysis of the Determinants of the Performance of the Global Private Equity Funds Markets
}

\author{
M. Candasamy \\ KPMG Mauritius - Advisory, Mauritius \\ Bhavish Jugurnath \\ University of Mauritius, Moka, Mauritius
}

\begin{abstract}
Over the last decade, the private equity (PE) industry, primarily venture capital and leveraged buyout investments, has matured massively. Consequently, public interest towards that particular asset class has increased rapidly. This study seeks to empirically assess the determinants of private equity funds' (PEFs) performance around the world. The study comprises a panel data of 103 publicly traded PEFs globally for the period of 2007-2013. Generalized least squares (GLS) technique is employed to regress the explanatory variables. The objective is accentuated on the major contributing factors that make a PEF successful. The analysis, in this paper, examines the effect of fund size, investment size, geographical focus, and industrial specialization on return. The empirical results provide evidence that: (1) Fund size and industrial specialization were observed to have an insignificant influence on the funds' returns in our panels; (2) Investment size is positively related to fund performance, indicating that larger deal sizes exhibited superior performance level; and (3) Geographical focus exhibited a negative association with fund performance, leading to the conclusion that limited geographical deployment of funds or absence of market diversification resulted in a fall in funds' returns. Consequently, to proxy for return of funds, stock prices of listed PEFs under LPEQ listings were employed.
\end{abstract}

Keywords: private equity (PE), generalized least squares (GLS), fund performance, stock size, emerging markets, Europe, North America, global market

\section{Introduction}

The substantial growth of private equity funds (PEFs) in scale and success has brought with it increased scrutiny. Kaplan and Schoar (2005) observed that in spite of the indubitable importance of PE investments for the economy as a whole and the accompanying academic scrutiny, only a limited understanding of PE returns, capital flows, and their interrelation was witnessed. One of the main hindrances is the lack of available data.

$\mathrm{PE}$, as the name suggests, is largely exempt from public disclosure requirements. This absence of visibility in the performances and their determinants poses a great concern to limited partners (LPs). Intrinsically, institutional investors (i.e., banks, insurance companies, retirement or pension funds, hedge funds, investment advisors, and mutual funds) who wish to invest their profits or diversify their portfolios would demand certain assurance before investing in a PEF. As a result, understanding the major driving forces of PEFs' success would influence significantly their investment decisions. According to Harris, Jenkinson, and Kaplan (2013), fund cash flows

M. Candasamy, consultant, KPMG Mauritius - Advisory. Email: rcandasamy@kpmg.mu.

Bhavish Jugurnath, lecturer, Faculty of Law and Management, University of Mauritius. 
information is frequently not disclosed and the source of the data is sometimes obscure, resulting in concerns about biases in the samples. Furthermore, some data are only periodically made available to academic researchers.

Investors, acting on behalf of a broad spectrum of the general public, are thoroughly observing any occurrence in the PE industry. Fact is that those PEFs hold assets involving public-interest funding. So far, theoretical studies (Gottschalg, Phalippou, \& Zollo, 2004; Kaplan \& Schoar, 2005) on the PE topic have focused largely on measuring its performance. Subsequently, funds were sampled exclusively in the US and Europe. We, therefore, judiciously observed that insufficient research work has been carried on a larger geographical scale and also on the determinants of PEF performance. Mitigating the trepidations for LP before investing in PEF is the main aspiration of our research. Based on the probable relationships that may exist between expected returns of funds and fund characteristics, investors would be more apt at making predictions and hence may finance high-achieving funds.

The remainder of this paper is organized as follows: Section two reviews the theoretical and empirical literature related to major researched PEF determinants and subsequently substantiates the research hypotheses. Section three presents the empirical research design of this research paper. Section four reports the empirical outcomes, and section five ultimately provides the overall conclusions of the study.

\section{Literature Review}

\section{Literature Related to Fund Size}

Major contributions made in establishing the determinants for PEF performance identified fund size as a driving force. The first one receiving wide attention was the study of Black and Gilson (1999) who observed that large fund size had the tendency to lower the relative management costs of the funds since the general partners (GPs) could benefit from economies of scale. This idea was initially broached forward by Gordon (1997), who elaborated on the fact that smaller funds, unable to inject sufficient capital into their portfolio companies, would often be obliged to call for larger funds as co-investors. Consequently, the minority stake holding of small venture capital (VC) funds would significantly weaken their negotiation power. Bigger VC fund would force lower valuations and more advantageous terms for their participation.

Kaplan and Schoar (2005) found that the relationship between past performance and fund size was positive and concave, at the fund level. However, this analysis applied solely to VC funds and not BO funds. The concavity, the authors argued, was attributed to the limited number of profitable deals, arising when fund grew beyond certain threshold.

Empirical evidences on fund size. Kaplan and Schoar (2005) estimated the relationship between fund size and performance using logistic regressions. Their findings, using a data sample of 1,090 funds from venture economics (VE), showed that the top performing funds in the PE industry grew less than proportionally with the increase in performance than did the lower performers. Given that most LPs claimed that the top funds are all highly oversubscribed, results displayed that better funds voluntarily chose to stay smaller. This observation explained the persistence in performance in PEFs. By growing relatively less rapidly than the market on a performance-adjusted basis, top funds were able to avoid moving into regions of diminishing returns.

Diller and Kaserer (2005), using a data set of 200 mature European PEFs over the period from 1980 to 2003 provided by Thomson Venture Economics (TVE), were able to develop a regression model. They used the weighted least squares (WLS) regression approach as returns seem to be affected by heteroscedasticity. Their paper analyzed the determinants of return generated by PEFs and the impact of fund inflows. They concluded that fund size had a positive impact on performance. 
Interestingly, Harris et al. (2013) tested the relationship between performance and fund size by classifying funds into size quartiles by decade. They studied the performance of 1,400 US BO and VC funds from the dataset of Burgiss from 1984 to 2008. Their results revealed that the average returns by size quartile did not demonstrate a strong correlation between fund size and performance. The only noticeable relationship was that the smallest quartile of both BO and VC funds seemed to have lower performance. The investigation was carried out through fund-level regressions of public-market-equivalents (PME) on fund size quartiles. It can be noted that their results were consistent with the findings of Lopez-de-Silanes, Phalippou, and Gottschalg (2011) who likewise did not establish any relationship between BO fund size and returns.

\section{Literature Related to Industrial Specialization and Geographical Focus}

Industrial specialization. Indubitably, the vast majority of PEFs specialize in one or more industries. Therefore, it is clear that diversification across industries of portfolio companies has a major impact on fund returns. Among the key scholars who pondered upon this field, Sapienza, Manigart, and Vermeir (1996) found evidence that VC funds with specialization experience were superior in value creation for their portfolio companies. Murray (1999) opined that as a means to mitigate and manage their risks, a number of VCs became specialists in one or a small number of closely-related sectors rather than numerous industries.

In line with this, Lockett, Murray, and Wright (2002) further commented that concentrating in one particular industry enabled the fund managers to enhance their industry-specific capabilities and experience. Compliant with this reasoning, De Clerq (2003) as well stipulated that narrow industrial focus and early stage specialization proved to have a positive correlation with performance.

According to Wang and Ang (2004), venture capitalists should continue to specialize by industry, as the specialization can reduce VC's vulnerability to the complex interactions of industry structure, strategy, and environment by limiting their investments to industries with high munificence environment under the conditions of limited hostility.

Ironically, we note that academics recommended specialization as a risk management technique rather than diversification. Nonetheless, there are opponents to industry specialization, who claim that restraining the investment areas decreases the funds deal flow and forces it to invest in mediocre companies.

Geographical specialization. Geographical specialization as well as industrial specialization determines how narrow the focus of the fund is. Initially, Manigart (1994) affirmed that specific geographic focus had a negative correlation with performance, in spite of local network effects which gave a positive correlation. A couple of earlier academic studies have explicitly compared PE investments across a number of developing countries. Hege, Palomino, and Schwienbacher (2009) presented a study of contractual determinants of success in venture financing, by comparing the conditions in US VC market with those in a relatively newer market for venture financing (Europe). Their data showed that US VC firms exhibited a significantly higher performance on average than their European counterparts, in terms of both type of exit and rate of return.

Concurrently, Hege et al. (2009) found that US VC firms on average exhibited significantly higher performances in terms of internal rate of return (IRR) than their European counterparts. This result was supported by Phalippou and Gottschalg (2009), who tested the data including both VC and BO funds. Manigart (1994) found that European VC firms with a local focus generated lower returns on average than VCs with broader geographical focuses. This further highlighted the significance of geographical scope as a driving force. 
In further literature, Groh and Von Liechtenstein (2009) fashioned a study to assess the attractiveness in Central and Eastern Europe; to establish the importance of several emerging markets allocation criteria for VC and PE investors. Later on, they complemented their work with composite indices to establish a comparison in terms of PE investment attractiveness across 27 European countries, based on 42 different socio-economic data series. They established that investors' protection and corporate governance rules and the size and liquidity of its capital market were the contributing factors to performance.

Empirical evidences on specialization. Bernstein, Lerner, Sorensen, and Stromberg (2010) set up a sample consisting of 8,596 country-industry-year observations of OECD countries between 1991 and 2007 and applied an ordinary least squares (OLS) regression. They noted that the impact of PE activity was different in continental Europe than in the US and UK. Not only was the level of PE activity higher in those two, but also the industry was more established where investments were in specialized fields.

In a study performed by Shvediuk and Sysak (2012) to assess the performance of 52 Nordic PEFs, they measured the geographic specialization and industrial specialization using concentration technique. Assuming as a proxy, the concentration of investments across the aforementioned dimensions, they were able to assess the specialization of funds. The percentage fund investments across industries/geographic regions were calculated and eventually employed to build up the Herfindahl-Hirschman Index of industrial/geographical concentration as sum of squared shares. The results concluded positive for industrial specialization index and negative for geographical specialization.

The purpose of this study being to investigate the impact of specific fund characteristics and strategies on performance, hence several hypotheses have been formulated in order to achieve that aim. The alternative hypotheses fashioned are as follows and their null hypotheses $\left(\mathrm{H}_{0}\right)$ being their contrary:

$\mathrm{H}_{1}$ : Fund size has an impact on returns.

$\mathrm{H}_{2}$ : Investment size has an impact on returns.

$\mathrm{H}_{3}$ : Specific geographical focus (out of five regions) in investment impacts on returns.

$\mathrm{H}_{4}$ : Industrial specialization has an impact on returns.

\section{Research Design}

This section provides a description of the data set used in this paper and the procedure used to construct the dependent variable and the regressors, including the descriptive statistics. The study will follow on in determining the association of return with the independent variables using the Pearson correlation test. Note that variables for return and investment size will be in natural logarithmic forms.

\section{Dependent Variable}

The dependent variable in this model is return. As per Shvediuk and Sysak (2012), there could be several dependent variables to measure performance; but for the purpose of this study, only one was chosen. However, ambiguity upon how return will be calculated can easily arise. For this model, performance will be calculated from the stock prices. The calculation for the fund return will be the appreciation in the price divided by the original price of the stock (inclusive of dividends), as shown below:

$$
\text { Return }=\frac{P_{1}}{P_{0}}-1
$$


where:

$P_{1}$ : The closing stock price;

$P_{0}$ : The opening stock price.

\section{Independent Variables}

Fundsiz. Fund size of the PEFs will be tested as a determinant for performance. We will measure fund size by the total amount of capital committed. That is, the amount of capital collected for the fund during the fundraising process. Previous studies, for example, Kaplan and Schoar (2005) and Harris et al. (2013), have revealed that fund size can alter performance with economies of scale effects. However, past documentations have also shown contradicting results with diverse forms of positive and negative correlations with performance.

Invsiz. Investment size is technically the amount of capital injection that PEFs make into their portfolio companies and deals. In order to cater for the large dispersion of investment amounts across the numerous funds, we will record data for the minimum and maximum amount of investment and hence calculate an average value for each fund. Hence, we will attempt to investigate whether the average investment sizes affect the fund returns.

Geo. Geographical focus reflects the degree of diversification that funds have in terms of their investments across locations, claimed Shvediuk and Sysak (2012). Past studies have widely claimed the advantage of a wide geographical focus on the deal flow of PE firms and hence return. However, opponents of this theory have also opined that a wide focus increased costs and made management of those investments more tedious.

Specialization. Industry specialization essentially determines how narrow the funds focus is within one particular or numerous industries at once. Evidence as per the impact of industry specialization on return has been ambivalent over time. Opponents have argued that diversification between industries of portfolio companies had a positive effect on the returns of funds and that industry specialization tends to decrease the funds' deal flow and forced PE firms to invest in mediocre companies. On the other hand, Bernstein et al. (2010) opined that specialization within a particular sector helps the GPs develop their industry-specific capabilities and experience.

To analyze its impact, industry specialization will be divided into two broad categories, namely, generalist (funds investing in multiple sectors) and specialist (funds investing in a specific area). They will be represented by a dummy variable, whereby 1 will indicate "generalist" focus and 0 , its absence and as such "specialist" focus.

\section{Regression Model}

Consequently, our research goal is to assess whether the four abovementioned variables have any effect on PEF performance. Previous research works have demonstrated that these factors have correlations with performance and hence are expected to have an impact on this theoretical setup. The model is generalized in the format below into a multivariate regression equation:

$$
Y_{i}=\alpha+\beta_{1} \times \text { fundsiz }+\beta_{2} \times \text { invsiz }+\beta_{3} \times \text { geo }+\beta_{4} \times \text { specialization }+\varepsilon_{i t}
$$

where:

$Y_{i}$ : The value of the dependent variable, return at a specific time period;

$\alpha$ : The constant or intercept; 
$\beta_{i}$ : The regression coefficients of the corresponding independent variables;

$\varepsilon_{i t}$ : The error term.

Subsequently, in order to make the above equation into a linear form, logarithmic is taken on both sides of the equation on numerical figures. This is to improve the model fit. For instance, if the residuals are not normally distributed, then taking the logarithm of a skewed variable may improve the fit by altering the scale and making the variable more "normally" distributed.

Note also that variables geo and specialization being nominal in nature will need to be transformed so as to be statistically fit for analysis. As such using dummies, the variables are redefined as follows (see Tables 1 and 2).

Table 1

Dummy Variables for Geo

\begin{tabular}{|l|l|}
\hline Geo & Description \\
\hline New variable & Emerging countries \\
\hline Georegion 1 & Europe \\
\hline Georegion 2 & Global \\
\hline Georegion 3 & North America \\
\hline Georegion 4 & Single country \\
\hline Georegion 5 &
\end{tabular}

Table 2

Dummy Variables for Specialization

\begin{tabular}{|l|l|}
\hline Specialization & Description \\
\hline New variable & Generalists \\
\hline Specialization 1 & Specialists \\
\hline Specialization 2 &
\end{tabular}

Hence, our redefined model integrates a total of 10 parameters (including the constant) and is as follows:

$$
\begin{gathered}
\ln \text { return }_{i}=\alpha+\beta_{1} \times \ln \text { fundsiz }_{i}+\beta_{2} \times \ln \text { invsiz }_{i}+\beta_{3} \times \text { georegion }_{i}+\beta_{4} \times \text { georegion }_{i} \\
+\beta_{5} \times \text { georegion }_{i}+\beta_{6} \times \text { georegion }_{i}+\beta_{7} \times \text { georegion }_{i} \\
+\beta_{8} \times{\text { specialization } 1_{i}}_{i}+\beta_{9} \times \text { specialization }_{i}+\varepsilon_{i t}
\end{gathered}
$$

\section{Empirical Results}

\section{Summary of Findings}

This study endeavored to empirically investigate the determinants of PEFs' performance around the world. The main concern addressed was based on what key elements would institutional investors, willing to diversify their portfolio, decide before investing in such funds. Assembling a panel of 103 publicly traded PE firms, we have examined this issue. Our research model regression was estimated using the GLS technique, owing to the panel's inherent heteroscedasticity and multicollinearity features. As such, we identified as potential determinants four major independent variables, namely, fund size, investment size, geographical focus, and industrial specialization. To proxy for performance, firms' stock returns were utilized. Intrinsically, to account for outlying data, our panel segregated year 2008 and 2011 so as to cater for their high dispersion. The analysis was conducted into three main geographical categories according to their market maturity. 
In spite of the broad-spectrum confession that the aforementioned variables were major determinants of PEF returns, our findings were somehow ambivalent (see Table 3 and 4). Regarding fund size, our findings were coherent with Harris et al. (2013), who could not significantly prove its association with return. As for investment size, we succeeded in proving a consistent causal link with performance. Adhering to the empirical evidences of Manigart (1994), we established a significant negative correlation between geographical specialization and return. However, industrial specialization's relationship to return level exhibited no statistical significance. Adhering to our pre-defined research objectives, we can therefore impartially opine that for institutional investors to endeavor any participation in a PEF through capital injection, it is primordial to contemplate the fund's investment strategies in terms of investment ticket and geographical target.

Table 3

Summary of Findings: Panel A

\begin{tabular}{|c|c|c|c|c|c|c|}
\hline \multirow{2}{*}{ Variable } & \multicolumn{2}{|c|}{ Group US } & \multicolumn{2}{|c|}{ Group EUROPE } & \multicolumn{2}{|c|}{ Group ROW } \\
\hline & Coef. & $P>|z|$ & Coef. & $P>|z|$ & Coef. & $P>|z|$ \\
\hline Fundsiz & -0.085 & 0.028 & -0.022 & 0.358 & -0.135 & 0.253 \\
\hline Invsiz & 0.078 & 0.133 & 0.032 & 0.233 & 0.093 & 0.315 \\
\hline Georegion 1 & -0.730 & 0 & 0.111 & 0.238 & 0.210 & 0.23 \\
\hline Georegion2 & -0.106 & 0.553 & 0.088 & 0.158 & 0.472 & 0.208 \\
\hline Georegion3 & 0.161 & 0.368 & 0.211 & 0.005 & 0.251 & 0.166 \\
\hline Georegion4 & 0.000 & - & 0.217 & 0.318 & 0.000 & - \\
\hline Georegion5 & & & 0.000 & - & & \\
\hline Specialization 1 & -0.117 & 0.187 & -0.002 & 0.965 & 0.088 & 0.502 \\
\hline Specialization 2 & 0.000 & - & 0.000 & - & 0.000 & - \\
\hline _cons & 0.586 & 0.008 & 0.061 & 0.583 & 0.5061 & 0.138 \\
\hline Number of obs. & 125 & & 335 & & 55 & \\
\hline$R$-squared & 0.1441 & & 0.0430 & & 0.0452 & \\
\hline Prob. > Chi2 & 0.0029 & & 0.1401 & & 0.8931 & \\
\hline
\end{tabular}

Table 4

Summary of Findings: Panel B

\begin{tabular}{|c|c|c|c|c|c|c|c|c|c|c|c|c|}
\hline \multirow{3}{*}{ Variable } & \multicolumn{4}{|c|}{ Group US } & \multicolumn{4}{|c|}{ Group EUROPE } & \multicolumn{4}{|c|}{ Group ROW } \\
\hline & \multicolumn{2}{|c|}{2008 return } & \multicolumn{2}{|c|}{2011 return } & \multicolumn{2}{|c|}{2008 return } & \multicolumn{2}{|c|}{2011 return } & \multicolumn{2}{|c|}{2008 return } & \multicolumn{2}{|c|}{2011 return } \\
\hline & Coef. & $P>|t|$ & $\overline{\text { Coef. }}$ & $P>|t|$ & Coef. & $P>|t|$ & Coef. & $P>|t|$ & Coef. & $P>|t|$ & Coef. & $P>|t|$ \\
\hline Fundsiz & 0.397 & 0.012 & -0.049 & 0.382 & -0.077 & 0.207 & -0.009 & 0.842 & -0.037 & 0.911 & 0.201 & 0.594 \\
\hline Invsiz & -0.495 & 0.018 & 0.077 & 0.305 & 0.043 & 0.532 & -0.061 & 0.224 & 0.020 & 0.939 & -0.212 & 0.483 \\
\hline Georegion 1 & 1.643 & 0.109 & -2.636 & 0.000 & 0.000 & - & 0.000 & & 0.109 & 0.825 & -0.452 & 0.430 \\
\hline Georegion2 & -0.779 & 0.413 & -0.224 & 0.537 & 0.725 & 0.004 & -0.028 & 0.871 & 0.329 & 0.756 & -0.164 & 0.889 \\
\hline Georegion3 & 0.000 & - & 0.000 & - & 0.294 & 0.268 & 0.073 & 0.703 & 1.674 & 0.025 & 0.366 & 0.530 \\
\hline Georegion4 & 0.441 & 0.512 & -0.153 & 0.550 & 0.502 & 0.400 & -0.366 & 0.392 & 0.000 & - & 0.000 & - \\
\hline Georegion5 & - & - & - & - & 0.508 & 0.040 & -0.055 & 0.754 & - & - & - & - \\
\hline Specialization 1 & 0.433 & 0.201 & -0.087 & 0.494 & 0.081 & 0.559 & 0.063 & 0.523 & 0.156 & 0.675 & -0.213 & 0.611 \\
\hline Specialization 2 & 0.000 & - & 0.000 & - & 0.000 & - & 0.000 & - & 0.000 & - & 0.000 & - \\
\hline _cons & -2.577 & 0.046 & 0.094 & 0.841 & -0.802 & 0.017 & 0.070 & 0.764 & -0.729 & 0.463 & -0.335 & 0.756 \\
\hline
\end{tabular}




\section{Conclusions}

This study showed that differences in terms of location of funds, their geographical focus, and investment strategies had a meaningful impact on performance. Therefore, institutional investors should carefully evaluate the features of the PEFs that they invest in, so as to maximize their expected rate of return. We noted that larger deal sizes yielded higher performances, hence suggesting that the long-term benefit of the investor will rely on its defined funding capacity. The empirical results in this study provide evidence that fund size and industrial specialization have an insignificant influence on the funds' returns in our panels. Geographical focus exhibited a negative association with fund performance, leading to the conclusion that limited geographical deployment of funds or absence of market diversification resulted in a fall in funds' returns. As always, research opens up to new avenues and hence scope for future studies. Restrictions with regards to data disclosure have limited us to analyze only four determinants. However, as claimed by Lerner and Schoar (2005), the legal environment in which the PE firms operate profoundly influences the transactions into which those PE groups enter. A similar reasoning was attributed to Bernoth, Colavecchio, and Sass (2010) who, this time, identified the macro-economic environment as a key determinant. Further scrutiny would undoubtedly increase the precision of this topic. Furthermore, in Panel B, we noted that the 2008 financial crisis and 2011 European sovereign debt crisis severely impacted on the return level of US PEFs with portfolio companies in Europe and emerging countries. This could pave the way for further probing as to how PE firms from developing markets have reacted during such dire periods.

\section{References}

Bernoth, K., Colavecchio, R., \& Sass, M. (2010). Drivers of private equity investment in CEE and Western European countries. DIW Berlin (German Institute for Economic Research) Discussion Paper No. 1002.

Bernstein, S., Lerner, J., Sorensen, M., \& Stromberg, P. (2010). Private equity and industry performance. NBER Working Paper 15632.

Black, B. S., \& Gilson, R. J. (1999). Does venture capital require an active stock market? Journal of Applied Corporate Finance, 11(4), 36-48.

De Clerq, D. (2003). A knowledge-based view of venture capital firms' portfolio investment specialization and syndication. Paper Presented at the Babson Kauffman Entrepreneurship Research Conference (BKERC), 2002-2006, Babson College.

Diller, C., \& Kaserer, C. (2005). What drives cash flow based European private equity returns? Fund inflows, skilled GPs and/or risk? RICAFE Working Paper No. 15.

Gordon, D. (1997). Will the real value fund please stand up? Money, 26(4), 140-142.

Gottschalg, O., Phalippou, L., \& Zollo, M. (2004). Performance of private equity funds: Another puzzle? INSEAD Working Paper.

Groh, A. P., \& Von Liechtenstein, H. (2009). How attractive is central Eastern Europe for risk capital investors? Journal of International Money and Finance, 28(4), 625-647.

Harris, R. S., Jenkinson, T., \& Kaplan, S. N. (2013). Private equity performance: What do we know? Working Paper No. 1932316.

Hege, U., Palomino, F., \& Schwienbacher, A. (2009). Venture capital performance: The disparity between Europe and the United States. Finance, 30(1), 7-50.

Kaplan, S. N., \& Schoar, A. (2005). Private equity performance: Returns, persistence, and capital flows. Journal of Finance, 60(4), 1791-1823.

Lerner, J., \& Schoar, A. (2005). Does legal enforcement affect financial transactions? The contractual channel in private equity. Quarterly Journal of Economics, 120(1), 223-246.

Lockett, A., Murray, G., \& Wright, M. (2002). Do UK venture capitalists still have a bias against investment in new technology firms? Research Policy, 31(6), 1009-1030. 
Lopez-de-Silanes, F., Phalippou, L., \& Gottschalg, O. (2011). Giants at the gate: On the cross-section of private equity investment returns. Tinbergen Institute Discussion Papers 11-035/2/DSF12, Tinbergen Institute.

Manigart, S. (1994). The founding rate of venture capital firms in three European countries (1970-1990). Journal of Business Venturing, 9(6), 525-541.

Murray, G. (1999). Early-stage venture capital funds, scale economies and public support. Venture Capital, 1(4), 351-384.

Phalippou, L., \& Gottschalg, O. (2009). The performance of private equity funds. Review of Financial Studies, 22(4), 1747-1776.

Sapienza, H. J., Manigart, S., \& Vermeir, W. (1996). Venture capitalist governance and value added in four countries. Journal of Business Venturing, 11(6), 439-469.

Shvediuk, V., \& Sysak, V. (2012). Performance drivers of Nordic private equity funds (Master thesis, BI Norwegian Business School).

Wang, C. K., \& Ang, B. L. (2004). Determinants of venture performance in Singapore. Journal of Small Business Management, 42(4), 347-363.

\section{Appendix A}

Table A1

Pooled OLS Regression

\begin{tabular}{|c|c|c|c|c|c|c|}
\hline \multirow{2}{*}{$\frac{\text { Return }}{\text { Fundsiz }}$} & \multirow{2}{*}{$\begin{array}{l}\text { Coef. } \\
-0.0203502\end{array}$} & \multirow{2}{*}{$\begin{array}{r}\text { Std. error } \\
0.0181687\end{array}$} & \multirow{2}{*}{$\begin{array}{l}t \\
-1.12\end{array}$} & \multirow{2}{*}{$\frac{p>|t|}{0.263}$} & \multicolumn{2}{|c|}{ [95\% conf. interval] } \\
\hline & & & & & -0.0560208 & 0.0153204 \\
\hline Invsiz & 0.0173734 & 0.0210064 & 0.83 & 0.408 & -0.0238684 & 0.0586152 \\
\hline Georegion 1 & -0.1288076 & 0.0722187 & -1.78 & 0.075 & -0.2705943 & 0.0129791 \\
\hline Georegion2 & -0.0515761 & 0.0617164 & -0.84 & 0.404 & -0.1727437 & 0.0695914 \\
\hline Georegion3 & 0 & (Omitted) & & & & \\
\hline Georegion4 & -0.0277063 & 0.0642137 & -0.43 & 0.666 & -0.1537769 & 0.0983643 \\
\hline Georegion5 & -0.1374889 & 0.0654244 & -2.10 & 0.036 & -0.2659364 & -0.0090414 \\
\hline Specialization 1 & -0.0029285 & 0.0404554 & -0.07 & 0.942 & -0.0823543 & 0.0764974 \\
\hline Specialization2 & 0 & (Omitted) & & & & \\
\hline _cons & 0.1224593 & 0.1039675 & 1.18 & 0.239 & -0.0816598 & 0.3265784 \\
\hline Source & SS & $\mathrm{df}$ & MS & Number of obs. & 721 & \\
\hline Model & 1.83887297 & 7 & 0.262696139 & $F(7,713)$ & 1.08 & \\
\hline Residual & 173.450965 & 713 & 0.243269236 & Prob. $>F$ & 0.3744 & \\
\hline \multirow[t]{3}{*}{ Total } & 175.289838 & 720 & 0.243458108 & $R$-squared & 0.0105 & \\
\hline & & & & Adj. $R$-squared & 0.0008 & \\
\hline & & & & $\begin{array}{l}\text { Root mean } \\
\text { square error }\end{array}$ & 0.49322 & \\
\hline
\end{tabular}

Table A2

Pooled Model: Correlation Matrix (Number of Observations = 721)

\begin{tabular}{|c|c|c|c|c|c|c|c|c|c|c|}
\hline Variable & Return & Fundsiz & Invsiz & Georeg-1 & Georeg-2 & Georeg-3 & Georeg-4 & Georeg-5 & Specia-1 & Specia-2 \\
\hline Return & 1.0000 & & & & & & & & & \\
\hline Fundsiz & 0.0016 & 1.0000 & & & & & & & & \\
\hline Invsiz & 0.0196 & 0.7501 & 1.0000 & & & & & & & \\
\hline Georeg-1 & -0.0408 & -0.1920 & -0.1162 & 1.0000 & & & & & & \\
\hline Georeg-2 & 0.0196 & 0.1602 & 0.1893 & -0.2423 & 1.0000 & & & & & \\
\hline Georeg-3 & 0.0568 & 0.0273 & 0.0797 & -0.1573 & -0.2423 & 1.0000 & & & & \\
\hline Georeg-4 & 0.0319 & 0.2044 & 0.0053 & -0.2186 & -0.3368 & -0.2186 & 1.0000 & & & \\
\hline Georeg-5 & -0.0665 & -0.2430 & -0.1776 & -0.2127 & -0.3276 & -0.2127 & -0.2955 & 1.0000 & & \\
\hline Specia-1 & 0.0242 & 0.0346 & 0.1587 & -0.0658 & -0.0098 & 0.1719 & 0.0669 & -0.1448 & 1.0000 & \\
\hline Specia-2 & -0.0242 & -0.0346 & -0.1587 & 0.0658 & 0.0098 & -0.1719 & -0.0669 & 0.1448 & -1.0000 & 1.0000 \\
\hline
\end{tabular}




\section{Appendix B}

Table B1

Fixed-Effects Panel Data Analysis

$R$-squared:

Within $\quad 0.0000$

Between

Overall

Corr (u_i, Xb)

Number of obs. $\quad 721$

Number of groups 103

Obs. per group:

Min. $\quad 7$

Avg. $\quad 7.0$

Max. $\quad 7$

$F(0,618) \quad 0.00$

Prob. $>F \quad-$

\begin{tabular}{|c|c|c|c|c|c|c|}
\hline Return & Coef. & Std. error & $t$ & $p>|t|$ & \multicolumn{2}{|c|}{ [95\% conf. interval] } \\
\hline Fundsiz & 0 & (Omitted) & & & & \\
\hline Invsiz & 0 & (Omitted) & & & & \\
\hline Georegion 1 & 0 & (Omitted) & & & & \\
\hline Georegion 2 & 0 & (Omitted) & & & & \\
\hline Georegion 3 & 0 & (Omitted) & & & & \\
\hline Georegion 4 & 0 & (Omitted) & & & & \\
\hline Georegion 5 & 0 & (Omitted) & & & & \\
\hline Specialization 1 & 0 & (Omitted) & & & & \\
\hline Specialization 2 & 0 & (Omitted) & & & & \\
\hline _cons & -0.0248211 & 0.0186329 & -1.33 & 0.183 & -0.0614126 & 0.0117704 \\
\hline sigma_u & 0.1698227 & & & & & \\
\hline sigma_e & 0.5003207 & & & & & \\
\hline rho & 0.10330883 & raction of va & due to $\mathrm{u} \_\mathrm{i}$ ) & & & \\
\hline
\end{tabular}

$F$-test that all u_i $=0: F(102,618)=0.81$; Prob. $>F=0.9114$

Table B2

GLS Random-Effects Panel Data Analysis

\begin{tabular}{ll}
\hline & \multicolumn{2}{c}{ Random-effects GLS regression (group variable: fund) } \\
\hline$R$-squared: & 0.0000 \\
Within & 0.0893 \\
Between & 0.0105 \\
Overall & 0 (assumed) \\
\hline Corr (u_i, X) & 721 \\
Number of obs. & 103 \\
Number of groups & \\
\hline Obs. per group: & 7 \\
Min. & 7.0 \\
Avg. & 7 \\
Max. & 7.56 \\
\hline Wald chi2 (7) & 0.3731 \\
Prob. $>$ chi2 &
\end{tabular}


(Table B2 continued)

\begin{tabular}{|c|c|c|c|c|c|c|}
\hline Return & Coef. & Std. error & $z$ & $p>|z|$ & \multicolumn{2}{|c|}{ [95\% conf. interval] } \\
\hline Fundsiz & -0.0203502 & 0.0181687 & -1.12 & 0.263 & -0.0559603 & 0.0152599 \\
\hline Invsiz & 0.0173734 & 0.0210064 & 0.83 & 0.408 & -0.0237984 & 0.0585452 \\
\hline Georegion 1 & 0.0086813 & 0.0632411 & 0.14 & 0.891 & -0.1152691 & 0.1326316 \\
\hline Georegion2 & 0.0859128 & 0.0545722 & 1.57 & 0.115 & -0.0210468 & 0.1928724 \\
\hline Georegion3 & 0.1374889 & 0.0654244 & 2.10 & 0.036 & 0.0092595 & 0.2657183 \\
\hline Georegion4 & 0.1097826 & 0.0582048 & 1.89 & 0.059 & -0.0042967 & 0.2238618 \\
\hline Georegion5 & 0 & (Omitted) & & & & \\
\hline Specialization 1 & -0.0029285 & 0.0404554 & -0.07 & 0.942 & -0.0822195 & 0.0763626 \\
\hline Specialization 2 & 0 & (Omitted) & & & & \\
\hline _cons & -0.0150296 & 0.0868902 & -0.17 & 0.863 & -0.1853313 & 0.1552721 \\
\hline sigma_u & 0 & & & & & \\
\hline sigma_e & 0.5003207 & & & & & \\
\hline rho & 0 (fraction o & variance due & & & & \\
\hline
\end{tabular}

Appendix C: Detailed Regressions Tables for Panel A: No Outliers

Table C1

GLS Regression: USA

\begin{tabular}{|c|c|c|c|c|c|c|}
\hline \multicolumn{7}{|c|}{ Random-effects GLS regression (group variable: fund) } \\
\hline \multicolumn{7}{|l|}{$R$-squared: } \\
\hline Within & - & & & & & \\
\hline Between & 0.6627 & & & & & \\
\hline Overall & 0.1441 & & & & & \\
\hline Corr (u_i, X) & 0 (assumed) & & & & & \\
\hline Number of obs. & 125 & & & & & \\
\hline Number of groups & 25 & & & & & \\
\hline \multicolumn{7}{|l|}{ Obs. per group: } \\
\hline Min. & 5 & & & & & \\
\hline Avg. & 5.0 & & & & & \\
\hline Max. & 5 & & & & & \\
\hline Wald chi2 (6) & 19.87 & & & & & \\
\hline Prob. > chi2 & 0.0029 & & & & & \\
\hline Return & Coef. & Std. error & $z$ & $p>|z|$ & \multicolumn{2}{|c|}{ [95\% conf. interval] } \\
\hline Fundsiz & -0.0847836 & 0.038586 & -2.20 & 0.028 & -0.1604108 & -0.0091565 \\
\hline Invsiz & 0.0776727 & 0.0517398 & 1.50 & 0.133 & -0.0237355 & 0.1790808 \\
\hline Georegion 1 & -0.7295794 & 0.1801497 & -4.05 & 0.000 & -1.082666 & -0.3764926 \\
\hline Georegion2 & -0.1057134 & 0.1782261 & -0.59 & 0.553 & -0.4550301 & 0.2436032 \\
\hline Georegion3 & 0.1606939 & 0.1786307 & 0.90 & 0.368 & -0.1894158 & 0.5108036 \\
\hline Georegion4 & 0 & (Omitted) & & & & \\
\hline Specialization 1 & -0.1167634 & 0.0885564 & -1.32 & 0.187 & -0.2903309 & 0.056804 \\
\hline Specialization 2 & 0 & (Omitted) & & & & \\
\hline _cons & 0.5863506 & 0.2199379 & 2.67 & 0.008 & 0.1552801 & 1.017421 \\
\hline sigma_u & 0 & & & & & \\
\hline sigma_e & 0.37308766 & & & & & \\
\hline rho & 0 (fraction of & variance due & & & & \\
\hline
\end{tabular}


Table C2

GLS Regression: EUROPE

\begin{tabular}{|c|c|c|c|c|c|c|}
\hline \multicolumn{7}{|c|}{ Random-effects GLS regression (group variable: fund) } \\
\hline \multicolumn{7}{|l|}{$R$-squared: } \\
\hline Within & 0.0000 & & & & & \\
\hline Between & 0.1567 & & & & & \\
\hline Overall & 0.0430 & & & & & \\
\hline Corr (u_i, X) & 0 (assumed) & & & & & \\
\hline Number of obs. & 335 & & & & & \\
\hline Number of groups & 67 & & & & & \\
\hline \multicolumn{7}{|l|}{ Obs. per group: } \\
\hline Min. & 5 & & & & & \\
\hline Avg. & 5.0 & & & & & \\
\hline Max. & 5 & & & & & \\
\hline Wald chi2 (7) & 10.97 & & & & & \\
\hline Prob. > chi2 & 0.1401 & & & & & \\
\hline Return & Coef. & Std. error & $z$ & $p>|z|$ & \multicolumn{2}{|c|}{ [95\% conf. interval] } \\
\hline Fundsiz & -0.0216849 & 0.0235974 & -0.92 & 0.358 & -0.067935 & 0.0245651 \\
\hline Invsiz & 0.0319642 & 0.0268166 & 1.19 & 0.233 & -0.0205954 & 0.0845237 \\
\hline Georegion 1 & 0.1111985 & 0.094233 & 1.18 & 0.238 & -0.0734948 & 0.2958917 \\
\hline Georegion2 & 0.0879113 & 0.0622542 & 1.41 & 0.158 & -0.0341046 & 0.2099272 \\
\hline Georegion3 & 0.2106123 & 0.0748211 & 2.81 & 0.005 & 0.0639656 & 0.357259 \\
\hline Georegion4 & 0.2174169 & 0.2176238 & 1.00 & 0.318 & -0.2091179 & 0.6439518 \\
\hline Georegion5 & 0 & (Omitted) & & & & \\
\hline Specialization 1 & -0.0023348 & 0.0535614 & -0.04 & 0.965 & -0.1073132 & 0.1026437 \\
\hline Specialization 2 & 0 & (Omitted) & & & & \\
\hline _cons & 0.0609131 & 0.1110584 & 0.55 & 0.583 & -0.1567574 & 0.2785836 \\
\hline sigma_u & 0.11275114 & & & & & \\
\hline sigma_e & 0.37624351 & & & & & \\
\hline rho & 0.08240523 & raction of var & due to & & & \\
\hline
\end{tabular}

Table C3

GLS Regression: ROW

\begin{tabular}{ll}
\hline \multicolumn{2}{c}{ Random-effects GLS regression (group variable: fund) } \\
\hline$R$-squared: & - \\
Within & 0.6168 \\
Between & 0.0452 \\
Overall & 0 (assumed) \\
\hline Corr (u_i, X) & 55 \\
Number of obs. & 11 \\
Number of groups & 11 \\
\hline Obs. per group: & \\
Min. & 5 \\
Avg. & 5.0 \\
Max. & 5 \\
\hline Wald chi2 (6) & 2.27 \\
Prob. $>$ chi2 & 0.8931 \\
\hline
\end{tabular}


(Table C3 continued)

\begin{tabular}{lllllll}
\hline Return & Coef. & Std. error & $z$ & $p>|z|$ & \multicolumn{1}{l}{ [95\% conf. interval] } \\
\hline Fundsiz & -0.1350514 & 0.1181975 & -1.14 & 0.253 & -0.3667143 & 0.0966114 \\
Invsiz & 0.0933692 & 0.093014 & 1.00 & 0.315 & -0.0889349 & 0.2756733 \\
Georegion1 & 0.2100641 & 0.1750609 & 1.20 & 0.230 & -0.133049 & 0.5531772 \\
Georegion2 & 0.4724936 & 0.3751375 & 1.26 & 0.208 & -0.2627623 & 1.20775 \\
Georegion3 & 0.2506126 & 0.1810193 & 1.38 & 0.166 & -0.1041788 & 0.6054039 \\
Georegion4 & 0 & (Omitted) & & & \\
Specialization 1 & 0.0878092 & 0.1309416 & 0.67 & 0.502 & -0.1688315 & 0.34445 \\
Specialization 2 & 0 & (Omitted) & & & \\
_cons & 0.5061326 & 0.3415424 & 1.48 & 0.138 & -0.1632783 & 1.175544 \\
sigma_u & 0 & & & & & \\
sigma_e & 0.28253047 & & & & & \\
rho & 0 (fraction of variance due to u_i) & &
\end{tabular}

Appendix D: Detailed Regressions Tables for Panel B: Outlying Years

Table D1

Linear Regression: US (Year 2008)

\begin{tabular}{|c|c|c|c|c|c|c|}
\hline Return & Coef. & Std. error & $t$ & $p>|t|$ & \multicolumn{2}{|c|}{ [95\% conf. interval] } \\
\hline Fundsiz & 0.3965026 & 0.1424124 & 2.78 & 0.012 & 0.0973054 & 0.6956999 \\
\hline Invsiz & -0.4952162 & 0.1909603 & -2.59 & 0.018 & -0.8964089 & -0.0940235 \\
\hline Georegion 1 & 1.642601 & 0.9755389 & 1.68 & 0.109 & -0.4069304 & 3.692132 \\
\hline Georegion 2 & -0.778891 & 0.9292816 & -0.84 & 0.413 & -2.731239 & 1.173457 \\
\hline Georegion3 & 0 & (Omitted) & & & & \\
\hline Georegion 4 & 0.4411361 & 0.6592865 & 0.67 & 0.512 & -0.9439735 & 1.826246 \\
\hline Specialization 1 & 0.4333832 & 0.3268423 & 1.33 & 0.201 & -0.2532869 & 1.120053 \\
\hline Specialization 2 & 0 & (Omitted) & & & & \\
\hline _cons & -2.57659 & 1.202084 & -2.14 & 0.046 & -5.102076 & -0.0511046 \\
\hline Source & SS & df & MS & Number of obs. & 25 & \\
\hline Model & 4.10130236 & 6 & 0.683550393 & $F(6,18)$ & 1.94 & \\
\hline Residual & 6.32693461 & 18 & 0.351496367 & Prob. $>F$ & 0.1281 & \\
\hline \multirow[t]{3}{*}{ Total } & 10.428237 & 24 & 0.434509874 & $R$-squared & 0.3933 & \\
\hline & & & & Adj. $R$-squared & 0.1911 & \\
\hline & & & & $\begin{array}{l}\text { Root mean } \\
\text { square error }\end{array}$ & 0.59287 & \\
\hline
\end{tabular}

Table D2

Linear Regression: EUROPE (Year 2008)

\begin{tabular}{|c|c|c|c|c|c|c|}
\hline \multirow{2}{*}{$\frac{\text { Return }}{\text { Fundsiz }}$} & \multirow{2}{*}{$\begin{array}{l}\text { Coef. } \\
-0.077416\end{array}$} & \multirow{2}{*}{$\begin{array}{l}\text { Std. error } \\
0.0606677\end{array}$} & \multirow{2}{*}{$\frac{t}{-1.28}$} & \multirow{2}{*}{$\frac{p>|t|}{0.207}$} & \multicolumn{2}{|c|}{ [95\% conf. interval] } \\
\hline & & & & & -0.1988119 & 0.0439798 \\
\hline Invsiz & 0.0433253 & 0.068944 & 0.63 & 0.532 & -0.0946313 & 0.1812819 \\
\hline Georegion 1 & 0 & (Omitted) & & & & \\
\hline Georegion 2 & 0.7252702 & 0.2425522 & 2.99 & 0.004 & 0.2399244 & 1.210616 \\
\hline Georegion3 & 0.2944185 & 0.2639723 & 1.12 & 0.269 & -0.2337888 & 0.8226258 \\
\hline Georegion 4 & 0.5023817 & 0.5926253 & 0.85 & 0.400 & -0.6834588 & 1.688222 \\
\hline Georegion5 & 0.507886 & 0.242268 & 2.10 & 0.040 & 0.0231088 & 0.9926633 \\
\hline Specialization 1 & 0.0809789 & 0.1377036 & 0.59 & 0.559 & -0.1945654 & 0.3565232 \\
\hline Specialization 2 & 0 & (Omitted) & & & & \\
\hline _cons & -0.8016858 & 0.3253124 & -2.46 & 0.017 & -1.452634 & -0.1507373 \\
\hline
\end{tabular}


(Table D2 continued)

\begin{tabular}{lcrlll}
\hline Source & SS & df & MS & Number of obs. & 67 \\
\hline Model & 3.44808878 & 7 & 0.492584111 & $F(7,59)$ & 1.82 \\
Residual & 15.9986525 & 59 & 0.271163601 & Prob. $>F$ & 0.1009 \\
Total & 19.4467413 & 66 & 0.294647595 & $R$-squared & 0.1773 \\
& & & Adj. $R$-squared & 0.0797 \\
& & & Root mean & 0.52073 \\
& & & square error & \\
\hline
\end{tabular}

Table D3

Linear Regression: ROW (Year 2008)

\begin{tabular}{|c|c|c|c|c|c|c|}
\hline Return & Coef. & Std. error & $t$ & $p>|t|$ & \multicolumn{2}{|c|}{ [95\% conf. interval] } \\
\hline Fundsiz & -0.0371383 & 0.3110815 & -0.12 & 0.911 & -0.900839 & 0.8265624 \\
\hline Invsiz & 0.0200037 & 0.2448016 & 0.08 & 0.939 & -0.6596746 & 0.699682 \\
\hline Georegion 1 & 0.1087585 & 0.4607391 & 0.24 & 0.825 & -1.170458 & 1.387975 \\
\hline Georegion 2 & 0.3292591 & 0.9873163 & 0.33 & 0.756 & -2.41197 & 3.070489 \\
\hline Georegion 3 & 1.673685 & 0.4764209 & 3.51 & 0.025 & 0.3509282 & 2.996441 \\
\hline Georegion 4 & 0 & (Omitted) & & & & \\
\hline Specialization 1 & 0.1558392 & 0.3446223 & 0.45 & 0.675 & -0.8009857 & 1.112664 \\
\hline Specialization2 & 0 & (Omitted) & & & & \\
\hline _cons & -0.7291389 & 0.8988982 & -0.81 & 0.463 & -3.224881 & 1.766603 \\
\hline Source & SS & df & MS & Number of obs. & 11 & \\
\hline Model & 2.43645136 & 6 & 0.406075227 & $F(6,4)$ & 3.89 & \\
\hline Residual & 0.417762576 & 4 & 0.104440644 & Prob. $>F$ & 0.1048 & \\
\hline \multirow[t]{3}{*}{ Total } & 2.85421394 & 10 & 0.285421394 & $R$-squared & 0.8536 & \\
\hline & & & & Adj. $R$-squared & 0.6341 & \\
\hline & & & & $\begin{array}{l}\text { Root mean } \\
\text { square error }\end{array}$ & 0.32317 & \\
\hline
\end{tabular}

Table D4

Linear Regression: US (Year 2011)

\begin{tabular}{|c|c|c|c|c|c|c|}
\hline Return & Coef. & Std. error & $t$ & $p>|t|$ & \multicolumn{2}{|c|}{ [95\% conf. interval] } \\
\hline Fundsiz & -0.0488503 & 0.0544786 & -0.90 & 0.382 & -0.1633056 & 0.0656049 \\
\hline Invsiz & 0.0771919 & 0.0730502 & 1.06 & 0.305 & -0.0762807 & 0.2306646 \\
\hline Georegion 1 & -2.635832 & 0.3731837 & -7.06 & 0.000 & -3.419862 & -1.851802 \\
\hline Georegion2 & -0.2238457 & 0.3554884 & -0.63 & 0.537 & -0.9706992 & 0.5230077 \\
\hline Georegion3 & 0 & (Omitted) & & & & \\
\hline Georegion4 & -0.1534625 & 0.2522042 & -0.61 & 0.550 & -0.6833238 & 0.3763989 \\
\hline Specialization 1 & -0.087198 & 0.1250306 & -0.70 & 0.494 & -0.3498776 & 0.1754816 \\
\hline Specialization2 & 0 & (Omitted) & & & & \\
\hline _cons & 0.0937317 & 0.4598467 & 0.20 & 0.841 & -0.8723704 & 1.059834 \\
\hline Source & SS & $\mathrm{df}$ & MS & Number of obs. & 25 & \\
\hline Model & 5.87798106 & 6 & 0.97966351 & $F(6,18)$ & 19.05 & \\
\hline Residual & 0.925869063 & 18 & 0.05143717 & Prob. $>F$ & 0.0000 & \\
\hline \multirow[t]{3}{*}{ Total } & 6.80385012 & 24 & 0.283493755 & $R$-squared & 0.8639 & \\
\hline & & & & Adj. $R$-squared & 0.8186 & \\
\hline & & & & $\begin{array}{l}\text { Root mean } \\
\text { square error }\end{array}$ & 0.2268 & \\
\hline
\end{tabular}


Table D5

Linear Regression: EUROPE (Year 2011)

\begin{tabular}{|c|c|c|c|c|c|c|}
\hline \multirow{2}{*}{$\frac{\text { Return }}{\text { Fundsiz }}$} & \multirow{2}{*}{$\begin{array}{l}\text { Coef. } \\
-0.0086831\end{array}$} & \multirow{2}{*}{$\begin{array}{r}\text { Std. error } \\
0.04347\end{array}$} & \multirow{2}{*}{$\frac{t}{-0.20}$} & \multirow{2}{*}{$\frac{p>|t|}{0.842}$} & \multicolumn{2}{|c|}{ [95\% conf. interval] } \\
\hline & & & & & -0.0956663 & 0.0783001 \\
\hline Invsiz & -0.0606886 & 0.0494001 & -1.23 & 0.224 & -0.1595381 & 0.0381608 \\
\hline Georegion 1 & 0 & (Omitted) & & & & \\
\hline Georegion2 & -0.0283921 & 0.1737949 & -0.16 & 0.871 & -0.3761548 & 0.3193706 \\
\hline Georegion3 & 0.0725442 & 0.1891429 & 0.38 & 0.703 & -0.3059298 & 0.4510183 \\
\hline Georegion4 & -0.3662062 & 0.4246312 & -0.86 & 0.392 & -1.215891 & 0.4834788 \\
\hline Georegion5 & -0.0545918 & 0.1735912 & -0.31 & 0.754 & -0.4019471 & 0.2927635 \\
\hline Specialization 1 & 0.0633384 & 0.0986682 & 0.64 & 0.523 & -0.1340961 & 0.260773 \\
\hline Specialization 2 & 0 & (Omitted) & & & & \\
\hline _cons & 0.0702561 & 0.2330946 & 0.30 & 0.764 & -0.3961652 & 0.5366773 \\
\hline Source & SS & $\mathrm{df}$ & MS & Number of obs. & 67 & \\
\hline Model & 0.841081902 & 7 & 0.120154557 & $F(7,59)$ & 0.86 & \\
\hline Residual & 8.21385071 & 59 & 0.139217809 & Prob. $>F$ & 0.5409 & \\
\hline \multirow[t]{3}{*}{ Total } & 9.05493261 & 66 & 0.137195949 & $R$-squared & 0.0929 & \\
\hline & & & & Adj. $R$-squared & -0.0147 & \\
\hline & & & & $\begin{array}{l}\text { Root mean } \\
\text { square error }\end{array}$ & 0.37312 & \\
\hline
\end{tabular}

